Marquette University

e-Publications@Marquette

Economics Faculty Research and Publications

Economics, Department of

$6-1-2010$

\title{
Trust in Others: Does Religion Matter?
}

Joseph P. Daniels

Marquette University, joseph.daniels@marquette.edu

Marc von der Ruhr

St Norbert College

Accepted version. Review of Social Economy, Vol. 68, No. 2 (June 2010): 163-186. DOI. (C) 2010

Taylor \& Francis. Used with permission. 


\title{
Trust in Others: Does Religion Matter?
}

\author{
Joseph P. Daniels \\ Department of Economics, Marquette University \\ Milwaukee, WI \\ Marc von der Ruhr \\ Department of Economics, St. Norbert College \\ De Pere, WI
}

\begin{abstract}
Though the recent literature offers intuitively appealing bases for, and evidence of, a linkage among religious beliefs, religious participation and economic outcomes, evidence on a relationship between religion and trust is mixed. By allowing for an attendance effect, disaggregating Protestant denominations, and using a more extensive data set, probit models of the General Social Survey (GSS), 1975 through 2000, show that black Protestants, Pentecostals, fundamentalist Protestants, and Catholics, trust others less than individuals who do not claim a preference for a particular denomination. For conservative denominations the effect of religion is through affiliation, not attendance. In contrast, liberal Protestants trust others more and this effect is reinforced by attendance. The impact of religion on moderate Protestants is only through attendance, as frequency of attendance increases trust of others while the denomination effect is insignificant.
\end{abstract}


NOT THE PUBLISHED VERSION; this is the author's final, peer-reviewed manuscript. The published version may be accessed by following the link in the citation at the bottom of the page.

Keywords: Religion, Social trust

\section{Introduction}

Until recently, economists have tended to either minimize or ignore altogether the potential impact of cultural factors on economic efficiency and performance. Within the past few years, however, there has been a renewed interest among economists regarding social trust and religion and their effect on individual attitudes and economic outcomes. Guiso et al., (2003) discuss the problem of causality possibility working in both directions in studies of cultural factors and economic outcomes. Their claim is that religion practices evolve only over very long time horizons and therefore can be treated as time invariant over an individual's lifetime. In cross-country studies (Guiso et al. 2003, 2006), they then postulate a link between culture, in which they include religious groups, and economic outcomes. Their hypothesis is that culture impacts economic preferences (such as labor market participation, trust, thriftiness, and fertility) and, in turn, economic outcomes. Likewise Barro and McCleary (2003, 2006) invoke Weber's argument that religious beliefs matter for important economic behavior such as honesty and trust in affecting economic performance. In a similar manner, Daniels and von der Ruhr (2005) focus on international economic policy issues and argue that religious affiliation has an important impact on an individual's view of others and therefore impacts attitudes toward trade and immigration policy, while Torgler (2006a) finds that religiosity correlates positively with tax compliance and (2006b) positively with trust in international organizations such as the United Nations. The common theme is that religious beliefs shape attitudes (such as trust) which, in turn, impact economic performance.

Although these authors make an intuitively appealing basis for a linkage between religious beliefs, participation, and economic outcomes, a significant relationship between religion and trust is mixed at best. In another cross-country study, Smidt (1999) finds not only a statistically significant lower level of social trust in the United States than in Canada (based on means comparison), but also a positive correlation between trust and church attendance even while controlling for denomination. Additionally, he finds that, again based on a 
comparison of mean values, black Protestants and Evangelical Protestants in the United States are generally less trusting than other denominations while mainline are Protestants more trusting.

There are few studies, however, on what exactly might add to or reduce social trust. Putnam's (2000) sweeping survey of the American social landscape is one important exception. Putnam's hypothesis is that there has been a decline in social trust over time because of waning voluntary participation in civic, social, and religious networks. Putnam also observes that it has been the newer evangelical religious denominations that have experienced growth and that these denominations tend to focus community efforts inward rather than outward. He concludes that (p. 79) "trends in religious life reinforce rather than counterbalance the ominous plunge in social connectedness in the secular community." Further, as Arrow (2000) and Putnam (2000) point out, and Glaeser et al. (1996) demonstrate in their study of social interactions and crime, there can be a "dark side" to social capital, as social interactions can have negative effects as well as positive. For example, social capital may reinforce stratification among groups in society.

Recently, economists and sociologists have been interested in the various determinants of social trust. The most recent studies of the determinants of social trust in the United States include Alesina and La Ferrara (2002) and Welch et al. (2004) who specifically investigate the role of religion. Alesina and La Ferrara use 20 years of General Social Survey (GSS) data, including among other factors, dummy variables for Protestant, Catholic, Jewish, and other religions. Regarding the religion controls, they find that (p. 220), "interestingly, these variables are totally insignificant." Welch et al. (2004) focus specifically on the link between religion and individual trust. They employ a single year (2000) of National Election Study (NES) data to examine the link between an individual's religious affiliation and attendance and their trust. They conclude (p. 336) that "contrary to many social commentators and democratic theorists," conservative Protestant beliefs do not reduce social trust (relative to individuals who do not claim a religious affiliation) and attendance does not correlate with social trust.

In this paper we also focus on the relationship between religious traditions, religious participation, and social trust in the United States.

Review of Social Economy, Vol 68, No. 2 (June 2010): pg. 163-186. DOI. This article is @ Routledge: Taylor \& Francis Group and permission has been granted for this version to appear in e-Publications@Marquette. Routledge: Taylor \& Francis Group does not grant permission for this article to be further copied/distributed or hosted elsewhere without the express permission from Routledge: Taylor \& Francis Group. 
In particular we hypothesize that religious participation generates trust of others, and that religious tradition or affiliation impacts an individual's trust of others, but that there are differential effects on individual trust across denominations. Our claim is that fundamentalist denominations are thick-tie networks (along the lines of Granovetter (1983)) that generate strong in-group trust (or bonding social capital as in Putnam (2000)) at the expense of others outside of the fundamentalist enclave. In other words, there is greater trust of those within the individual's religious network but lower trust of others in society in general. Liberal Protestant denominations, in contrast, are weak-tie networks that generate relatively more outward trust (or bridging social capital). That is, there is a greater emphasis on the role of the individual in society as a whole in these networks and, therefore, a greater level of trust of others in society in general than that of conservative denominations. Hence, participation and religious affiliation may exert reinforcing or offsetting effects on an individual's general or overall level of trust. In this application, "social trust" is the generalized trust of "others" in society. We are unable and do not test interpersonal trust or trust of others within specific networks, an extension that also deserves greater attention.

For comparison purposes, our study is designed to compare and contrast with Alesina and La Ferrara and with Welch et al. There are, however, some important differences. Contrasting with Alesina and La Ferrara, we extend the GSS data from 1994 to 2000, disaggregate Protestant into various logical groupings suggested by the literature, and include a measure of participation (attendance). We differ from Welch et al., by using the GSS data covering several years as opposed to a single year centered on a national election and its potential anomalies. In addition to the time dimension, the larger sample gives us an additional advantage in that our estimates of average effects of specific grouping of Protestant denominations are based on much larger samples. ${ }^{1}$ In contrast to both studies, we also investigate the time aspect of the data set.

The General Social Survey (GSS), 1975 through 2000, is used to empirically examine the propositions given above. The dependent variable of analysis is a standard question on the degree of trust of others in general. Based on probit models, our results show that black Protestants, Pentecostals, fundamentalist Protestants, and Catholics,

Review of Social Economy, Vol 68, No. 2 (June 2010): pg. 163-186. DOI. This article is (C Routledge: Taylor \& Francis Group and permission has been granted for this version to appear in e-Publications@Marquette. Routledge: Taylor \& Francis Group does not grant permission for this article to be further copied/distributed or hosted elsewhere without the express permission from Routledge: Taylor \& Francis Group. 
trust others less than those individuals who do not claim a preference for a particular religious denomination. For these denominations, the dominant effect of religion is through affiliation as there is only weak evidence of an attendance effect. In contrast, liberal Protestants trust others more and this effect is reinforced by attendance. The impact of religion on moderate Protestants is through attendance, as frequency of attendance increases trust of others while the denomination effect is insignificant. A time-trend is significant and negative, confirming the observations of Putnam and others that trust has been declining over time. The interaction of the time-trend with religious denominations and with religious attendance, however, is not significant. Hence, although membership in various denominations has changed over time, the contribution of various denominations and attendance does not appear to have.

The remainder of the paper is organized as follows. The second section offers a brief narrative of the theories on the determinants of social trust and provides hypotheses on how religion likely affects trust of others. The third section describes the data and empirical model. The fourth section provides and interprets the empirical results, while the final section offers a conclusion.

\section{Social Trust: Why Might Religion Matter?}

Theories on the determinants of social trust typically focus on either individual demographics and experiences, or the cultural and societal environment in which the individual resides. These two approaches are typically referred to as Individual Theory and Societal Theory. (See Delhey and Newton (2003) for a concise yet comprehensive survey of theories of the determinants of social trust.) Individual theories of trust postulate that successful and happy individuals are more trusting. In regard to economic success, the notion is that individuals in a tenuous economic situation have more to lose if their trust in someone else is violated. In other words, trust is a much riskier proposition to the poor. The marginal risk of placing trust in another to the successful and secure, however, is much lower. This view is consistent with Putnam's (2000: 138) observation that in virtually all societies the "haves" are more trusting than the "havenots." In addition, those who have been treated better by others tend to be more trusting. In general, therefore, individuals with lower levels 
of education, lower socioeconomic status, minorities, and those who have experienced divorce or separation are less likely to trust others.

According to societal theories, the second broad category of trust theories, individuals develop trust attitudes when interacting with other individuals in society, and likewise affect other individuals' attitudes. There are three non-mutually exclusive theories under the umbrella of societal theory. Voluntary Association Theory maintains that direct interaction with others on a sustained basis in voluntary organizations (such as a religion-based organization) builds social trust and, therefore, societies with dense and well-formed formal voluntary networks will generate relatively higher levels of social trust. Social Networks Theory, in contrast, claims that although direct interaction is still important, it is casual and impromptu interactions, such as chatting with a neighbor in line at the grocery, with neighbors you encounter at the local pub, or ad hoc contacts in informal networks, for example at work, that are vital. Another branch of Societal Theory, Community Theory, places importance on the characteristics of society itself. According to this approach, individuals who live in societies with higher levels of income equality and greater ethnic and racial homogeneity are more trusting. As Delhey and Newton stress, none of these theories are mutually exclusive and their measurement indicators often overlap. Empirical models, therefore, at the same time may find support for many or all of these theories.

\section{Relating and Testing the Social Theories of Trust and Religion}

Participation in a religion is the predominant form of voluntary association in the United States and, therefore, one might expect, a priori, that religious participation would be positive and significant in empirical models of trust. Otherwise, the voluntary association theories would appear suspect. Furthermore, given the diversity of religious denominations in the United States, one might also expect that the impact of participation in a religious network on individual trust would vary across denominations along the lines of Community Theory. Herein lies a dilemma for studying the link between religion and trust: theoretically there are two channels through which participation in a religion may affect trust. On the one hand, voluntary association theory would have that the frequency of participation in a 
religion-based network leads to an increase in trust. Community Theory, on the other hand, allows for different approaches to practicing one's faith and for those approaches to exert differential effects on individual trust. In other words, the religious denomination and its various customs, messages, and traditions are an important determinant of trust.

\section{Outcomes of Religious Participation}

According to Wuthnow (2002), religious participation has long been considered important as a "social resource," being a source of interpersonal networks and interaction, and has been shown to be an important determinant of other types of civic involvement. Smidt (1999) claims that religious life serves as an important contributor to civil society, and, more specifically, that religious beliefs may shape the ways in which individuals view human nature and the extent to which members of one religious community relate to those inside and outside of the community.

Along this line of reasoning, Coreno (2002: 337) argues that "... fundamentalists often form small interconnected independent denominations in the hope of protecting a quarantined traditionalist culture inside a network of church-based institutions. They nourish these enclave communities by separating themselves as much as possible from mainline churches in particular and secular culture in general." (See similar arguments by Ammerman (1998), Marsden (1991), and Tamney (1992).) Smith (1986) adds that southern fundamentalist denominations, in particular, support a stronger sense of this separatism attitude.

In the same literature, it is argued that moderate and liberal Protestants, in contrast, are less threatened by secular society and tend to thrive more in a modern world. They are also less concerned with biblical inerrancy and tend to treat religious beliefs as more personal and private. Further, moderate or mainline denominations tend to relate more inclusively with other denominations and engage more in ecumenical activities.

In regard to Catholics, Putnam (1993) argues that the hierarchical structure of the Roman Catholic Church in Italy hinders cooperation and trust. Smidt (1999), however, in a comparison of the

Review of Social Economy, Vol 68, No. 2 (June 2010): pg. 163-186. DOI. This article is (C Routledge: Taylor \& Francis Group and permission has been granted for this version to appear in e-Publications@Marquette. Routledge: Taylor \& Francis Group does not grant permission for this article to be further copied/distributed or hosted elsewhere without the express permission from Routledge: Taylor \& Francis Group. 
United States and Canada, finds that within the United States, Catholics tend to be more trusting of others than evangelical Protestants and less trusting than mainline Protestants, but Catholics ranked significantly lower than members of Protestant denominations in terms of civic engagement. Welch et al. (2004), in contrast, argue that, at least since Vatican II, there is no reason to expect that Catholics would trust any less than mainstream Protestants. They claim that the American Catholic Church is substantially different from the Church in Italy, and that most US Catholic parishes do not maintain a rigid boundary against the outside culture. Based on this literature we expect that Catholics would fall somewhere between fundamentalist Protestants and moderate Protestants in terms of social trust and do not expect a priori any difference between pre-Vatican II Catholics and post-Vatican II Catholics.

Hence, a thorough study of the impact of religion in individual trust must allow for: (1) affiliation effects; (2) participation effects; and (3) the interaction between affiliation and participation. We argue, therefore, that the differing approaches of Pentecostal, fundamentalist, moderate, and liberal Protestant denominations will be reflected in differing attitudes of trust among Protestant members. More specifically, we hypothesize that Pentecostal and fundamentalist denominations are thick-tie networks (along the lines of Granovetter (1983)) or bonding networks (Putnam 2000) that generate "thick trust" or strong in-group trust at the expense of "thin trust," or trust towards "others" outside of the fundamentalist enclave. Liberal Protestant denominations, in contrast, are weak-tie or bridging networks that generate relatively more outward trust. Hence, members of fundamentalist denominations are less likely to trust others than the non-affiliated and members of liberal denominations.

In an empirical study, the foregoing argument implies that aggregating Protestant denominations together in a single category (as in Alesina and La Ferrara (2002)), might result in the differing trust attitudes offsetting each other, leading to an incorrect conclusion that "religion" is a statistically insignificant determinant of individual trust. Yet, when considering sub groupings of individuals, one must ensure that the sample size of each subgroup is sufficient to yield a reasonable estimate of the "average" attitude of the subgroup. Our 
use of the GSS data while disaggregating the Protestant family of denominations addresses these concerns.

\section{Data and Model}

The previous sections motivate the following three testable hypotheses:

1. Members of conservative Protestant denominations are less likely to trust others, compared with the base group of individuals who do not claim a preference for a religious denomination.

2. Religious participation, in general and independent of affiliation, leads to greater trust of others.

3. Based on the claims of Putnam (2000) we should find, in addition, a statistically significant decline in trust over time. However, we have no expectations regarding whether the contribution of the various Protestant denominations and participation, in general, has been stable over time or has also evolved.

\section{Data}

Our data source is the General Social Survey (GSS) spanning the years 1975 through 2000. It is important to note that, because respondents to the GSS are different in each survey, this is pooled cross-sectional data, not panel data. Nonetheless, the time aspect of the data gives an interesting dimension to examine. That is, is there a general decline in trust as suggested by others, and are the contributions of various religious denominations and by religious attendance (in general) stable over time? Table 1 summarizes all of the variables and provides all of the specific years included in the empirical model. The dependent variable of the primary regression model is the response to the question: "Generally speaking, would you say that most people can be trusted, or that you can't be too careful in dealing with people?" Possible responses are; "most people can be trusted," "can't be too careful," "depends," "don't know," and "no answer." Because of the limited nature of the dependent variable, we follow Alesina and La Ferrara and code this as a binary model with unity assigned to the first category and zero to the remaining 
NOT THE PUBLISHED VERSION; this is the author's final, peer-reviewed manuscript. The published version may be accessed by following the link in the citation at the bottom of the page.

categories except for no-answer responses which are treated as missing observations.

Table 1: Summary Statistics

\begin{tabular}{|c|c|c|c|c|c|}
\hline Variable & Observations & $\begin{array}{c}\text { Mean/ } \\
\text { proportion }\end{array}$ & SD & Minimum & Maximum \\
\hline Trust & 24,615 & 0.3878 & 0.4873 & 0 & 1 \\
\hline Age & 31,309 & 45.2438 & 17.5684 & 18 & 89 \\
\hline Married & 31,400 & $53.95 \%$ & 0.4984 & 0 & 1 \\
\hline Female & 31,408 & $56.80 \%$ & 0.4954 & 0 & 1 \\
\hline African American & 31,408 & $13.25 \%$ & 0.3390 & 0 & 1 \\
\hline Education < 12 & 31,312 & $24.00 \%$ & 0.4271 & 0 & 1 \\
\hline Education $>16$ & 31,312 & $9.24 \%$ & 0.2895 & 0 & 1 \\
\hline Children & 31,298 & 1.9288 & 1.7881 & 0 & 8 \\
\hline Log Real income & 28,354 & 2.3065 & 0.0802 & 1.83 & 2.43 \\
\hline Full-time & 31,405 & $50.20 \%$ & 0.5000 & 0 & 1 \\
\hline Part-time & 31,405 & $10.42 \%$ & 0.3055 & 0 & 1 \\
\hline Divorced/separated & 31,400 & $15.76 \%$ & 0.3644 & 0 & 1 \\
\hline Happy & 31,113 & 2.2030 & 0.6275 & 1 & 3 \\
\hline Attendance ${ }^{1}$ & 30,924 & 22.0776 & 23.0224 & 0 & 60 \\
\hline
\end{tabular}

Source: General Social Survey, 1975-2000. Total of 31,408 observations. Specific years are: 1975, 1976, 1978, 1980,1983, 1984, 1986, 1987, 1988, 1989, 1990, $1991,1993,1994,1996,1998$, and 2000. Nine Census divisions are also included. Go to http://www.census.gov/geo/www/us_regdiv.pdf for a map of the regions and divisions.

${ }^{1}$ Attendance is annualized following Putnam (2000: 424): never $=0$, less than once a year $=0.5$, once a year $=I$, several times a year $=6$, once a month $=12,2-3$ times a month $=30$, nearly every week $=40$, every week $=52$, more than once a week $=60$.

Independent variables include demographic variables reflecting individual characteristics such as age and age squared (to allow for a non-linear effect of age), the number of children the respondent has, dummy variables for married, divorced or separated, female, African American, education of 12 years or less and education of 16 years or more, part-time employment and full-time employment. ${ }^{2}$ The log of the level of real income is also included as is the individual's response to a question on their general level of happiness. ${ }^{3}$ The happiness variable (Happy) is coded as 3 for the response of "very happy," 2 for "pretty happy," and 1 for "not too happy."

The individual's response to the question "what is your religious preference?" is included, beginning with the major denominations of

Review of Social Economy, Vol 68, No. 2 (June 2010): pg. 163-186. DOI. This article is @ Routledge: Taylor \& Francis Group and permission has been granted for this version to appear in e-Publications@Marquette. Routledge: Taylor \& Francis Group does not grant permission for this article to be further copied/distributed or hosted elsewhere without the express permission from Routledge: Taylor \& Francis Group. 
Protestant, Catholic, Jewish, and other religions. The base group, therefore, is individuals who did not report a preference for a specific denomination. The individual's reported attendance of religious services is also included. This variable measures the individual's reported frequency of attending religious services and ranges from "never" to "several times a week." Note that individuals who do not report a preferred religion may still report that they attend religious services (even if only attending at holidays, weddings and baptisms). A description of the attendance variable and statistics on the mean frequency of attendance across denominations is provided in Table 2.

\section{Table 2: Denominations and Attendance ${ }^{1}$}

\begin{tabular}{lrcc} 
Denomination & Proportion of total & $\mathrm{N}=31,408$ & Mean \\
\hline Protestant & $60.91 \%$ & 24.39 & 23.1727 \\
Black Protestant & $10.86 \%$ & 28.16 & 21.9273 \\
$\quad$ Fundamentalist & $23.15 \%$ & 27.85 & 24.4467 \\
Pentecostal & $2.59 \%$ & 34.18 & 25.1886 \\
Fundamentalist $^{2}$ & $20.55 \%$ & 27.04 & 24.2352 \\
Moderate & $13.80 \%$ & 20.30 & 22.0654 \\
Liberal & $12.66 \%$ & 19.21 & 21.1686 \\
Catholic & $24.70 \%$ & 25.08 & 22.9662 \\
Jewish & $1.99 \%$ & 10.04 & 16.0325 \\
Other religion & $2.26 \%$ & 18.09 & 22.3982 \\
No preference & $9.87 \%$ & 3.47 & 11.4589
\end{tabular}

Notes: ${ }^{1}$ Attendance is annualized following Putnam (2000: 424): never $=0$, less than once a year $=0.5$, once a year $=1$, several times a year $=6$, once a month $=12,2-3$ times a month $=30$, nearly every week $=40$, every week $=52$, more than once a week $=60$.

${ }^{2}$ Fundamentalist with Pentecostals removed.

See Table 1 for summary statistics on the attendance variable.

\section{Empirical Model}

The data described above represent our base model which we first compare with Alesina and La Ferrara (2002). Because of the limited nature of the dependent variable, a probit model is employed. All specifications of the empirical model include controls for the nine Census divisions and the year of the survey. The Huber/White/sandwich estimator of variance is used for robust standard errors and the clustering of respondents in metropolitan areas is controlled for using the size of the SMA. Listwise deletion is 
used for missing observations resulting in a different number of usable observations for each regression model. Reported coefficients are the maximum-likelihood estimates of the marginal effects calculated at the mean. Hence, the coefficients reflect the change in the probability given an infinitesimal change in the mean value of the independent variable. For dummy variables the marginal change is the discrete change from zero to unity. All $p$-values referenced in the text are for two-tailed tests unless otherwise noted.

\section{Results}

Model 1 in Table 3, reports results for the base model, which is provided for comparison purposes with the studies referenced earlier. The results indicate that trust rises with age, income, education, for those who work part-time, and for individuals who describe themselves as happy. Age squared indicates that the age effect is diminishing with increasing years of age with the maximum effect occurring at approximately age 66. In contrast, married individuals and individuals who are divorced or separated, females, African Americans, and individuals with 12 years or less of education are less likely to trust others (relative to their respective base groups). None of the religious denominations are individually significant. However, a test of the joint significance of the denomination variables, not examined in either Alesina and La Ferrara (2002) or Welch et al. (2004), yields a chi-square statistic of 9.47 (which is significant at the 5 percent level), so we may reject the hypothesis of no joint significance and the hypothesis of no difference among denominations. This motivates further investigation of the individual and joint significance of various sub-denominations. 
NOT THE PUBLISHED VERSION; this is the author's final, peer-reviewed manuscript. The published version may be accessed by following the link in the citation at the bottom of the page.

Table 3: Model Results

\begin{tabular}{|c|c|c|c|c|c|c|c|c|}
\hline & \multicolumn{2}{|c|}{ Model 1} & \multicolumn{2}{|c|}{ Model 2} & \multicolumn{2}{|c|}{ Model 3} & \multicolumn{2}{|c|}{ Model 4} \\
\hline & B & se & B & se & 6 & se & B & se \\
\hline Age Squared & $0.0132^{\star * \star}$ & {$[0.0013]$} & $0.0130^{\star \star \star}$ & {$[0.0013]$} & $0.0129^{\star \star \star}$ & [0.0013] & $0.0129^{\star \star \star}$ & {$[0.0013]$} \\
\hline Age Squared & $-0.0001^{\star \star \star}$ & {$[0.0000]$} & $-0.0001^{\star \star \star}$ & {$[0.0000]$} & $-0.0001^{\star \star \star}$ & {$[0.0000]$} & $-0.0001^{\star \star \star}$ & {$[0.0000]$} \\
\hline Married & $-0.0270^{\star \star \star}$ & [0.0084] & $-0.0272^{\star \star \star}$ & {$[0.0084]$} & $-0.0235^{\star \star \star}$ & {$[0.0087]$} & $-0.0232^{\star \star \star \star}$ & {$[0.0087]$} \\
\hline Female & $-0.0311^{\star \star \star}$ & {$[0.0074]$} & $-0.0328^{\star \star \star}$ & {$[0.0075]$} & $-0.0348^{\star \star \star}$ & {$[0.0077]$} & $-0.0348^{\star \star \star}$ & {$[0.0077]$} \\
\hline African American & $-0.2167^{\star \star \star}$ & {$[0.0095]$} & $-0.2216^{\star \star \star}$ & {$[0.0095]$} & $-0.1748^{\star \star \star}$ & {$[0.0198]$} & $-0.1739^{\star \star \star}$ & {$[0.0198]$} \\
\hline Education<12 & $-0.1768^{\star \star \star}$ & {$[0.0080]$} & $-0.1754^{\star \star \star}$ & {$[0.0080]$} & $-0.1673^{\star \star \star}$ & {$[0.0081]$} & $-0.1668^{\star \star \star}$ & {$[0.0081]$} \\
\hline Education $>16$ & $0.1592^{\star \star \star}$ & [0.0115] & $0.1561^{\star \star \star}$ & {$[0.0115]$} & $0.1495^{\star \star \star}$ & {$[0.0117]$} & $0.1492^{\star \star \star}$ & {$[0.0117]$} \\
\hline Children & -0.0029 & {$[0.0023]$} & -0.0034 & {$[0.0023]$} & -0.0023 & {$[0.0023]$} & -0.0023 & {$[0.0023]$} \\
\hline log Real Income & $0.4438^{* * *}$ & {$[0.0558]$} & $0.4449^{* \star *}$ & {$[0.0565]$} & $0.4077^{\star \star \star}$ & [0.0559] & $0.4048^{\star \star *}$ & {$[0.0558]$} \\
\hline Fulltime & 0.0117 & [0.0092] & 0.0123 & {$[0.0094]$} & 0.0128 & {$[0.0094]$} & 0.0127 & [0.0094] \\
\hline Parttime & $0.0515^{\star \star \star}$ & [0.0139] & $0.0507^{\star \star \star}$ & {$[0.0138]$} & $0.0495^{\star \star \star}$ & {$[0.0140]$} & $0.0492^{\star \star \star}$ & {$[0.0141]$} \\
\hline Divorced/Separated & $-0.0425^{\star \star \star}$ & {$[0.0116]$} & $-0.0405^{\star \star \star}$ & {$[0.0117]$} & $-0.0385^{\star \star \star}$ & {$[0.0118]$} & $-0.0383^{\star \star \star}$ & [0.0118] \\
\hline Happy & $0.0774^{\star \star \star}$ & {$[0.0051]$} & $0.0756^{\star \star \star}$ & {$[0.0053]$} & $0.0747^{\star \star \star}$ & [0.0053] & $0.0746^{\star \star \star}$ & {$[0.0053]$} \\
\hline Protestant & 0.0048 & {$[0.0121]$} & -0.0037 & {$[0.0123]$} & & & & \\
\hline Black Protestant & & & & & $-0.0821^{\star \star \star}$ & {$[0.0266]$} & $-0.0881^{\star \star \star}$ & {$[0.0267]$} \\
\hline Fundamentalist & & & & & $-0.0544^{\star \star \star}$ & [0.0129] & $-0.0553^{\star \star \star}$ & {$[0.0136]$} \\
\hline Pentecostal & & & & & & & $-0.0920^{\star \star \star}$ & {$[0.0218]$} \\
\hline Moderate & & & & & 0.0167 & [0.0135] & 0.0116 & {$[0.0138]$} \\
\hline Liberal & & & & & $0.0629^{\star \star \star}$ & {$[0.0145]$} & $0.0578^{\star \star \star}$ & {$[0.0148]$} \\
\hline Catholic & -0.0159 & [0.0134] & $-0.0247^{\star}$ & {$[0.0135]$} & $-0.0249^{\star}$ & [0.0134] & $-0.0303^{\star \star}$ & {$[0.0140]$} \\
\hline Jewish & 0.0064 & {$[0.0281]$} & 0.0045 & {$[0.0276]$} & 0.0138 & {$[0.0276]$} & 0.0091 & {$[0.0280]$} \\
\hline Other Religion & 0.0289 & {$[0.0221]$} & 0.023 & {$[0.0222]$} & 0.0177 & {$[0.0220]$} & -0.0062 & {$[0.0193]$} \\
\hline Attendance & & & $0.0005^{\star \star \star}$ & {$[0.0001]$} & $0.0007^{\star \star \star}$ & {$[0.0001]$} & $0.0008^{\star \star \star}$ & {$[0.0001]$} \\
\hline Observations & 21935 & & 21719 & & 21582 & & 21582 & \\
\hline Pseudo R-squared & $9.66 \%$ & & $9.71 \%$ & & $10.08 \%$ & & $10.09 \%$ & \\
\hline Observed Probability & 0.3950 & & 0.3957 & & 0.3951 & & 0.3951 & \\
\hline Predicted Probability & 0.3796 & & 0.3801 & & 0.3793 & & 0.3793 & \\
\hline
\end{tabular}

Dependent variable is: "Generally speaking, would you say that most people can be trusted or that you can't be too careful in dealing with people?" Robust standard errors are in brackets. $* * * \mathrm{p}<0.01, * * \mathrm{p}<0.05, * \mathrm{p}<0.1$, two-tailed tests. All models include year and census division controls and these results are available upon request.

\section{Attendance and Sub-denominations}

As explained earlier, attendance may, in and of itself, have an important effect as the extent of past interaction and expected future interaction in community networks may generate bridging trust, even if the individual is not committed to a particular tradition. In addition, various Protestant denominations or traditions may well have differential effects on their members. If either or both of the effects are indeed important, then the results in Model 1 suffer from omitted variable bias. Attendance is therefore added to Model 1 and the results are provided in Model 2 of Table 3. The results show that attendance is positive and significant at the 1 percent level. ${ }^{4}$ Including this variable also causes: (1) Catholic to become statistically significantly negative ( $p$-value of 7 percent) and (2) the chi-square statistic of joint significance of the four denominations to rise to 10.22 ( $p$-value of 3.69 percent).

The GSS data also includes a variable that sorts Protestant denominations in conservative, moderate, and liberal families based on

Review of Social Economy, Vol 68, No. 2 (June 2010): pg. 163-186. DOI. This article is (C Routledge: Taylor \& Francis Group and permission has been granted for this version to appear in e-Publications@Marquette. Routledge: Taylor \& Francis Group does not grant permission for this article to be further copied/distributed or hosted elsewhere without the express permission from Routledge: Taylor \& Francis Group. 
research conducted by the National Opinion Research Center (see Smith 1986, 1990). Model 3 of Table 3 introduces dummy variables to separate and control for fundamentalist, moderate and liberal traditions. In addition, we follow Coreno (2002) and Welch et al., who argue for a separate classification for Black Protestant denominations because of the unique historical experience of black denominations, coding all African Americans who claim a preference for a Protestant denomination in a separate variable. Note that this variable is slightly different from an interaction term between African American and Protestant, as African American Protestants are removed from the other Protestant categories to differentiate between black Protestant and white Protestant.

The results of Model 3 indicate that black Protestants and members of fundamentalist and Catholic traditions are less likely to trust others-relative to the base group of individuals who do not claim a preference for a particular denomination-while liberal Protestant traditions are more likely to trust others. ${ }^{5}$ Members of moderate Protestant traditions are not statistically significantly different from the base group. In addition, the chi-square statistic on the joint significance of the denomination variables rises to 150.23 and both the null hypothesis of all the coefficients on the denominations being simultaneously zero.

Welch et al.(2004) contend, and this is arguably the most important contribution of their work, that Pentecostal conservative Protestant traditions are distinct from other Protestant groupings as they establish the strongest social barriers and are therefore more likely to have a strong negative effect on social trust. If Pentecostal members are included in the fundamentalist group, as in Model 3, it may well be the source of the negative and significant effect. In Model 4, Pentecostals are separated from the other Protestant traditions. To do so, we use the denomination profiles of The Association of Religion Data Archives (http://www.thearda.com) at Pennsylvania State University to further sort the GSS data into Pentecostal families. Appendix 1 provides the denominations that are included in the Pentecostal variable.

The results of Model 4 show that the Pentecostal variable is indeed negative and statistically significant. Further, the inclusion of the additional classification had little impact on the sign and 
significance of the other denominations-except for a slight improvement in the $p$-value for Catholics - and little impact on the chisquare statistic of joint significance. As reported earlier, Welch et al. (2004) assert that Pentecostals are distinct from other Protestants because of an additional "individualizing" effect. Model 4, indeed, indicates a larger marginal effect for Pentecostals (in absolute value) than other denominations. Further hypotheses tests show no statistical difference between black Protestants and Pentecostals. The differences between Pentecostals and fundamentalists and Pentecostals and Catholics, however, are statistically significant ( $p$-values of 7.0 percent and 3.8 respectively) as is the difference between fundamentalist and Catholic ( $p$-value of 4.2 percent).

We simulate the change in the probability that an individual chooses that "most people can be trusted" under various scenarios using Clarify (Tomz et al. 2001; King et al. 2000) to better communicate the contribution of the different denominations to trust. The process followed was to estimate Model 4 of Table 3 and draw 1,000 sets of simulated parameters of the model. Values are then chosen for the explanatory variables to represent a baseline individual. Based on means and most frequent occurrences (see Tables 1 and 2), the baseline individual is the mean value for age, number of children, income, happiness, and attendance. The individual is also married, female, and white, works full time, has between 12 and 16 years of education, and lives in Census division 5. The midpoint of the sample period, 1988, was selected as the year and initially the individual has no preference for a particular religious denomination. Next, the probability that the baseline individual believes "most people can be trusted" is simulated.

To show the impact of various denominations on trust, the denomination of the baseline individual is changed to a specific denomination and the probability that the individual believes "most people can be trusted" is simulated again. (One important note is that, for black Protestant, the individual is still coded as white. Otherwise, the simulation would reflect both being African American and belonging to a black protestant denomination.) Figure 1 illustrates the difference in the probability that the individual of a particular denomination believes "most people can be trusted" from the probability of the baseline individual. As seen in Figure 1, being a

Review of Social Economy, Vol 68, No. 2 (June 2010): pg. 163-186. DOI. This article is @ Routledge: Taylor \& Francis Group and permission has been granted for this version to appear in e-Publications@Marquette. Routledge: Taylor \& Francis Group does not grant permission for this article to be further copied/distributed or hosted elsewhere without the express permission from Routledge: Taylor \& Francis Group. 
member of a liberal Protestant denomination increases the probability that an individual trusts others while being a Catholic or member of fundamentalist, Pentecostal, or black Protestant denomination reduces the probability that an individual trusts others. (Recall that moderate Protestant was not statistically significantly different from those individuals who do not claim a preference for a particular denomination.) The figure also clearly shows the differential effect on trust of the denominations, with Pentecostal and black Protestant reducing by the most the probability that an individual trusts others.

Figure 1 Contribution of Denominations to Trust

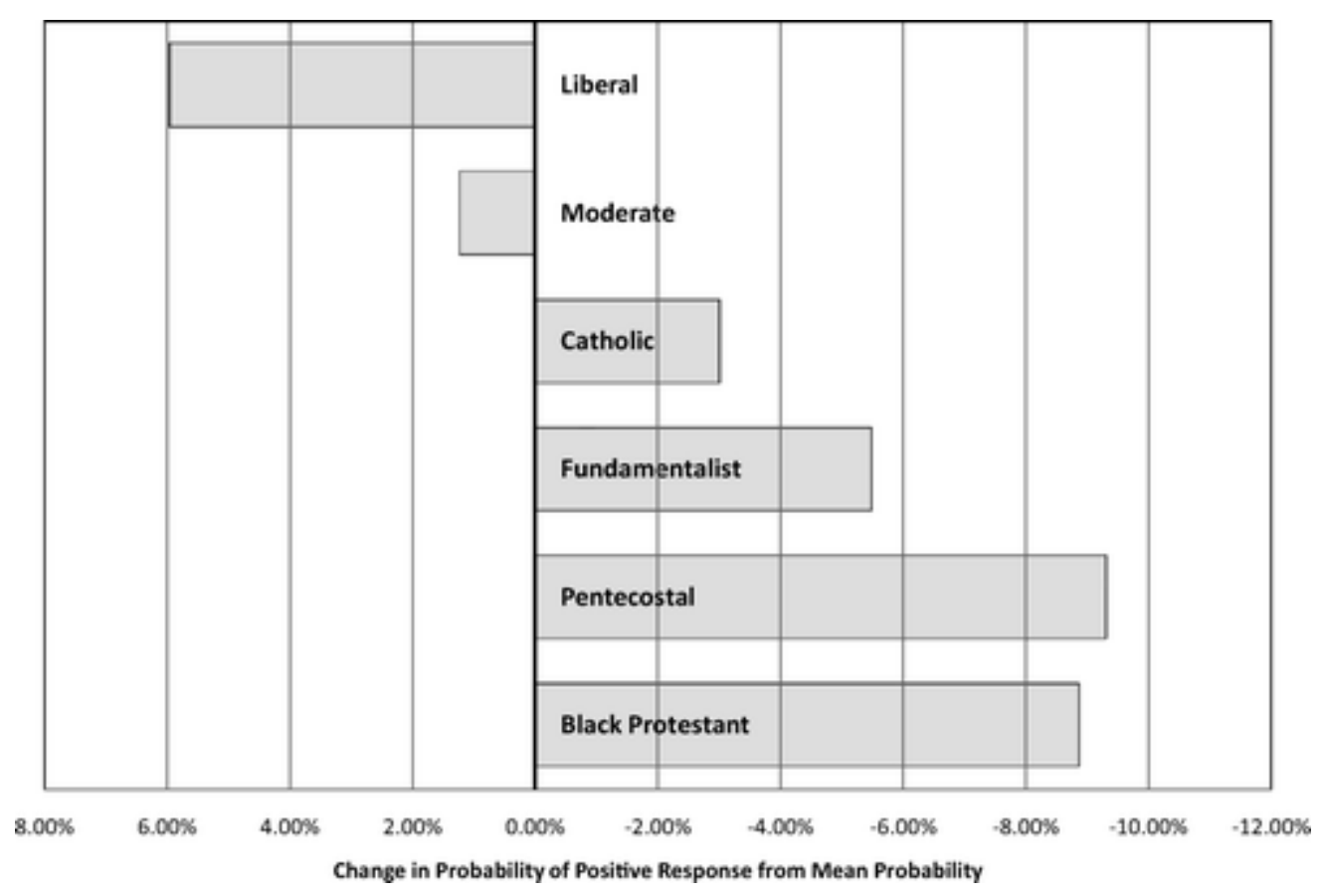

Models 2, 3, and 4, therefore, confirm our initial hypotheses, that members of conservative (Pentecostal and fundamentalist) Protestant denominations trust others less, members of liberal Protestant denominations trust others more, and participation, in general, leads to greater trust of others. ${ }^{6}$

\section{Interaction Effects}

The importance of the interaction effects is to determine if greater immersion in a particular denomination and, therefore, greater 
interaction with members of the denomination reinforces the denomination effect or moderates the denomination effect. Table 4 provides the interaction of attendance with the various subdenomination categories of Model 4 in Table 3. Note that after attendance has been interacted with all sub-denomination groupings, the coefficient of attendance itself reflects the impact of attendance on those individuals who do not have a preference for any particular denomination. Recall that an individual might not claim a preference for any particular denomination yet may or may not attend religious services. The coefficient on attendance is statistically insignificant, indicating that increased attendance does not affect the group of individuals who do not claim an affiliation.

\section{Table 4: Interaction Effects}

\begin{tabular}{|c|c|c|c|c|c|}
\hline Variable & B & se & Variable & $\beta$ & se \\
\hline Age Squared & $0.01291^{\star \star \star}$ & {$[0.00125]$} & Black Protestant & $-0.08562^{\star \star \star}$ & {$[0.03108]$} \\
\hline Age Squared & $-0.00010^{\star \star \star}$ & {$[0.00001]$} & Black Protestant $\times$ Attendance & 0.00184 & {$[0.00141]$} \\
\hline Married & $-0.02338^{\star \star \star}$ & {$[0.00870]$} & Fundamentalist & $-0.05708^{\star \star \star}$ & [0.01505] \\
\hline Female & $-0.03488^{\star \star \star}$ & {$[0.00767]$} & Fundamentalist $x$ Attendance & 0.00213 & {$[0.00133]$} \\
\hline African American & $-0.17071^{\star \star \star}$ & {$[0.02022]$} & Pentecostal & $-0.09430^{\star \star \star}$ & {$[0.03088]$} \\
\hline Education $<12$ & $-0.16658^{\star * *}$ & {$[0.00810]$} & Pentecostal x Attendance & 0.00217 & {$[0.00157]$} \\
\hline Education $>16$ & $0.14900^{\star \star \star \star}$ & [0.01183] & Moderate & -0.00387 & [0.01486] \\
\hline Children & -0.00223 & {$[0.00234]$} & Moderate $\times$ Attendance & $0.00277^{\star \star}$ & {$[0.00138]$} \\
\hline log Real Income & $0.40423^{\star \star *}$ & {$[0.05549]$} & Liberal & $0.04749^{* * *}$ & {$[0.01706]$} \\
\hline Fulltime & 0.01292 & {$[0.00947]$} & Liberal $\times$ Attendance & $0.00253^{\star}$ & [0.00139] \\
\hline Parttime & $0.04924^{\star \star \star}$ & {$[0.01404]$} & Catholic & $-0.03149^{\star \star}$ & {$[0.01528]$} \\
\hline Divorced/Separated & $-0.03825^{\star \star \star}$ & {$[0.01184]$} & Catholic $\times$ Attendance & 0.00209 & {$[0.00145]$} \\
\hline Happy & $0.07455^{\star \star \star}$ & {$[0.00531]$} & Jewish & 0.0099 & {$[0.03137]$} \\
\hline \multirow[t]{3}{*}{ Attendance } & -0.00144 & {$[0.00135]$} & Jewish $\times$ Attendance & 0.00167 & {$[0.00209]$} \\
\hline & & & Other Religion & -0.00778 & {$[0.02673]$} \\
\hline & & & Other Religion $x$ Attendance & 0.00205 & {$[0.00158]$} \\
\hline Observations & 21582 & & & & \\
\hline Pseudo R-squared & $10.11 \%$ & & & & \\
\hline Observed Probability & 0.3951 & & & & \\
\hline Predicted Probability & 0.3793 & & & & \\
\hline
\end{tabular}

Dependent variable is: "Generally speaking, would you say that most people can be trusted or that you can't be too careful in dealing with people?" Robust standard errors are in brackets. $* * * \mathrm{p}<0.01, * * \mathrm{p}<0.05, * \mathrm{p}<0.1$, two-tailed tests. Model includes year and census division controls whose results are available upon request.

The interaction terms are also insignificant for black Protestants, Pentecostals, fundamentalists, Catholics, Jewish, and other religions. For these denominations, therefore, the impact of religion occurs through the denomination effect and the level of attendance does not appear to either reinforce or moderate the denomination effect. In contrast, the interaction terms are positive and significant for both moderate and liberal Protestant denominations. Recall from Table 3 that moderate Protestant was not statistically significantly different from individuals with no denominational preference. Hence, the impact

Review of Social Economy, Vol 68, No. 2 (June 2010): pg. 163-186. DOI. This article is (C Routledge: Taylor \& Francis Group and permission has been granted for this version to appear in e-Publications@Marquette. Routledge: Taylor \& Francis Group does not grant permission for this article to be further copied/distributed or hosted elsewhere without the express permission from Routledge: Taylor \& Francis Group. 
on moderate Protestants is through attendance only. The interaction for liberal Protestants indicates that greater attendance reinforces the positive impact of affiliation on trust, and for this group, there exists both a denomination and attendance effect.

\section{Time Dimensions}

The GSS data allow us to consider potential changes in trust in general, and changes in the contribution of affiliation and attendance over time. To begin, we follow Guiso et al. (2003), and test for a Vatican II effect on Catholics by creating a dummy variable for those individuals born after 1962 . This variable is then interacted with the Catholic variable and both variables are included in Model 4. The interaction term is statistically insignificant providing no evidence of a Vatican II effect an Catholics' trust of others.

Putnam (2000) claims there is evidence of a downward trend in social trust since the 1960s. Costa and Kahn (2003), however, find the evidence of a trend in social capital mixed. To investigate a trend in our variable on social trust, we drop the controls for individual years and include a time trend and its square instead. We do not include these results in Table 3, and simply report that the trend was negative and significant at the 1 percent level, but the non-linear term was not significant. Furthermore, though there was no impact on the sign or significance of any of the model variables, there was a slight drop in the pseudo $\mathrm{R}^{2}$.

The time trend was next interacted with each of the denomination groups in Model 4. The only interaction term that was significant was Jewish, which was positive and significant with a $p$ value of 7 percent. The time trend alone, which in this model captures the impact of time on individuals who did not have a preference for a given denomination, remained negative and statistically significant. Hence, the contribution of the various denominational groupings in Model 4, other than Jewish, to trust appears to be robust over time in a statistical sense.

Finally, the time trend was interacted with attendance to examine if the impact of attendance, in general, has changed over time. Because of the nature of this variable, two dummy variables were created, one for relatively high attendance and one for relatively 
low attendance, leaving as the base group those individuals who never attend religious services. The high-attendance dummy included individuals that attend religious services at least once a week or more and the low-attendance dummy included individuals that attended at least once a year but less than once a week or more. The highattendance and low-attendance variables were positive and significant, but their interactions with the time variable were not. Hence, the impact of attendance appears to be robust over time as well. ${ }^{7}$ (All of the results regarding the time trend and its interaction are available upon request.)

This leaves us to consider further Putnam's (2000) claim that trends in religious practices and participation tend to reinforce the decline in social trust rather than counterbalance that trend. He makes his point explicit ( $p .78$ ) that it is the arguable decline in overall participation and the shifting of membership out of more moderate and liberal denominations toward more conservative evangelical denominations that renders religion in the United States as "less effective now as a foundation for civic engagement and bridging social capital." Although the results given here do not prove this claim, they do imply that the contribution of overall religious participation and the different effects of individual denominations to social trust are stable over time. We suggest that if religion is indeed less effective in generating social trust, it might be due to declining participation and a shift from liberal protestant denominations to fundamentalist and Pentecostal denominations and merits further investigation.

\section{Conclusion}

Recently there has been a renewed interest in the relationship between religion, social trust, and economic outcomes. This interest is likely motivated by two factors; the persistent and high rate of religious participation in the United States relative to most other advanced economies and, that religious participation arguably remains the most important form of voluntary participation in the United States. Although recent literature has provided compelling theoretical arguments for a relationship between social trust and religion, recent empirical yield mixed evidence. In particular, cross-country studies such as Guiso et al. (2003) and Barro and McCleary (2003) find an association between religious participation and trust, while studies on 
the United States such as Welch et al. (2004) and Alesina and La Ferrara (2002) find mixed or no evidence to support an association. In this paper we use GSS data spanning 25 years to test the relationship between trust and religious participation and affiliation. We hypothesize that greater frequency of participation in a religious network leads to an increased trust of others, while affiliation, in contrast, may have differential effects. Empirical results show that Pentecostals, fundamentalists, black Protestants, and Catholics are less likely to trust others, while members of liberal denominations are more likely to trust others. Hence, the trust attitudes of members of conservative and black Protestant denominations stand in stark contrast to those of moderate and liberal denominations. In addition, while controlling for the denomination effect, trust is increasing with the frequency that the individual attends religious services. Interaction of attendance and denomination, however, indicates frequency of attendance is not significant for black Protestants, Pentecostals, fundamentalists, Catholics, Jewish, and other religions. The interaction term is significant and positive for Moderate and Liberal Protestants.

In general, we find that religion does indeed play an important role in the formation of social trust. In addition, there are statistically significant differences among denominations and significant attendance effects. In addition, as suggested by Putnam (2000) and others, social trust in general has changed over time. Consequently, studies which aggregate sub- denominations to the majordenomination level and that omit attendance mask important affiliation effects of religion and overlook participation effects and studies that focus only on a single year of data may not truly reflect the contribution of religion to social trust. Recently there has been evidence of increase switching by individuals in the United States among various denominations. Survey measures of this phenomenon and its impact on general trust of others, currently not available in the GSS, would be an important new direction for future research.

\section{Acknowledgements}

The authors acknowledge with great appreciation the assistance provided by John Davis, Jim McGibany, two anonymous referees, and the students of the 2007 seminar on "The Economics of Religion" at Marquette University.

Review of Social Economy, Vol 68, No. 2 (June 2010): pg. 163-186. DOI. This article is @ Routledge: Taylor \& Francis Group and permission has been granted for this version to appear in e-Publications@Marquette. Routledge: Taylor \& Francis Group does not grant permission for this article to be further copied/distributed or hosted elsewhere without the express permission from Routledge: Taylor \& Francis Group. 
NOT THE PUBLISHED VERSION; this is the author's final, peer-reviewed manuscript. The published version may be accessed by following the link in the citation at the bottom of the page.

\section{Appendix 1: Denominations in the GSS Reclassified as Pentecostal ${ }^{1}$}

\begin{tabular}{ll}
\hline Assembly of God & Pentecostal Assembly of God \\
Apostolic Faith & Pentecostal Church of God \\
Church of Christ, Evangelical & Pentecostal \\
Church of Christ & Pentecostal Holiness, Holiness \\
Churches of God & Pentecostal \\
Church of God in Christ & United Holiness \\
Church of God in Christ Holiness & Holiness Church of God \\
Church of the Living God & Charismatic \\
Full Gospel & Pentecostal Apostolic \\
Four Square Gospel & \\
\hline
\end{tabular}

${ }^{1}$ See The Association of Religion Data Archives (ARDA) at http://www.thearda.com/Denoms/Families/F_94.asp

\section{Notes}

${ }^{1}$ Although Welch et al. do not provide the size of their various groupings of Protestant denominations, we are able to estimate their size using the appendix to the paper. It appears that some of the groups, fundamentalist Protestants for example, approach 30 individuals in number. Other groupings, of course, are much larger and provide reliable estimates for the year of their study.

${ }^{2}$ It was not possible to accurately code other ethnic groups, such as Hispanics, in this data set.

${ }^{3}$ Alesina and La Ferrara (2002) include the response to a question as to whether the individual has experienced a trauma in the past year. This question, however, was not asked over several years of the GSS survey, resulting in a greatly reduced sample size.

${ }^{4}$ Smidt (1999) claims that the relationship between social trust and attendance is curvilineary, as those who attend the least and those who attend the most as being less trusting. We included in our regressions: (1) the square of attendance, and (2) dummied in each category of positive attendance, yet found no evidence of a non-linear relationship.

${ }^{5}$ As an alternative to the coding of "black Protestant" described above, we also coded black Protestant as the three historically black denominations of National Baptist Convention in the USA, African Methodist Episcopal, and African Methodist Episcopal Zion. The only change in our results was that

Review of Social Economy, Vol 68, No. 2 (June 2010): pg. 163-186. DOI. This article is (C) Routledge: Taylor \& Francis Group and permission has been granted for this version to appear in e-Publications@Marquette. Routledge: Taylor \& Francis Group does not grant permission for this article to be further copied/distributed or hosted elsewhere without the express permission from Routledge: Taylor \& Francis Group. 
NOT THE PUBLISHED VERSION; this is the author's final, peer-reviewed manuscript. The published version may be accessed by following the link in the citation at the bottom of the page.

"black Protestant" was negative and statistically insignificant. This new grouping, however, had significantly fewer observations (266 versus 3,410 in the original variable).

${ }^{6}$ We also experimented with two additional dependent variables, "Do you think most people would try to take advantage of you if they got a chance, or would they try to be fair?" and "Would you say that most of the time people try to be helpful, or that they are mostly just looking out for themselves?" and a single variable that combined the three different questions on trust, fairness, and helpfulness together. The variable on fairness and the combined variable generated similar results as those presented here while the variable on helpfulness tended to show the religious participation variable as less statistically significant.

${ }^{7} \mathrm{An}$ important difference between the work here and that of Welch et al. (2004) is that Welch et al., use a single year, 2000, of National Election Survey data. One could hypothesize that an election cycle might well have an impact on individual trust. Hetherington (2005) shows that there has been a general decline in the public's trust of government, while Geer (2006) presents evidence that negative campaigning during an election cycle has a slight positive effect, if any at all, on trust of the government. We do not know of any systematic study of the impact of an election cycle on trust of other individuals. In Model 4 we dropped the year dummy and added a time trend and a dummy for presidential election years. The trend is negative and significant while the election dummy is positive and significant. This issue may be worthy of additional research.

\section{References}

1. Alesina, A. and La Ferrara, E. 2002. "Who Trusts Others?". Journal of Public Economics, 85: 207-234.

2. Ammerman, N. T. 1998. "North American Protestant Fundamentalism". In Media, Culture and the Religious Right, Edited by: Kintz, L. and Lesage, J. 55-114. Minneapolis, MN: University of Minnesota Press.

3. Arrow, K. J. 2000. "Observations on Social Capital". In Social Capital: A Multifaceted Perspective, Edited by: Dasgupta, P. and Serageldin, I. Washington, DC: The World Bank.

4. Barro, R. J. and McCleary, R. M. 2003. "Religion and Economic Growth Across Countries". American Sociological Review, 68(5): 766-781.

5. Barro, R. J. and McCleary, R. M. 2006. "Religion and Economy". Journal of Economic Perspectives, 20(2): 49-72.

Review of Social Economy, Vol 68, No. 2 (June 2010): pg. 163-186. DOI. This article is @ Routledge: Taylor \& Francis Group and permission has been granted for this version to appear in e-Publications@Marquette. Routledge: Taylor \& Francis Group does not grant permission for this article to be further copied/distributed or hosted elsewhere without the express permission from Routledge: Taylor \& Francis Group. 
6. Coreno, T. 2002. "Fundamentalism as a Class Culture". Sociology of Religion, 63(3): 335-360.

7. Costa, D. L. and Kahn, M. E. 2003. "Understanding the American Decline in Social Capital, 1952-1998". Kyklos, 56(1): 17-46.

8. Daniels, J. P. and von der Ruhr, M. 2005. "God and the Global Economy". Socio-Economic Review, 3(3): 467-490.

9. Delhey, J. and Newton, K. 2003. "Who Trusts? The Origins of Social Trust in Seven Nations". European Societies, 5(2): 93-137.

10. Geer, J. G. 2006. In Defense of Negativity, Chicago, IL: The University of Chicago Press.

11. Glaeser, E. L., Sacerdote, B. and Scheinkman, J. A. 1996. "Crime and Social Interactions". The Quarterly Journal of Economics, 111(2): 507-548.

12. Granovetter, M. 1983. "The Strength of Weak Ties: A Network Theory Revisited". Sociological Theory, 1: 201-333.

13. Guiso, L., Sapienza, P. and Zingales, L. 2003. "People's Opium? Religion and Economic Attitudes". Journal of Monetary Economics, 50(1): 225-282.

14. Guiso, L., Sapienza, P. and Zingales, L. 2006. "Does Culture Affect Economic Outcomes?". Journal of Economic Perspectives, 20(2): 23-48.

15. Hetherington, M. J. 2005. Why Trust Matters: Declining Political Trust and the Demise of American Liberalism, Princeton, NJ: Princeton University Press.

16. King, G., Tomz, M. J. and Wittenberg, J. 2000. "Making the most of Statistical Analysis: Improving Interpretation and Presentation". American Journal of Political Science, 44(2): 347361.

17. Marsden, G. M. 1991. Understanding Fundamentalism and Evangelicalism, Grand Rapids, MI: W.B. Eerdmans.

18. Putnam, R. D. 1993. Making Democracy Work: Civic Traditions in Modern Italy, Princeton, NJ: Princeton University Press.

19. Putnam, R. D. 2000. Bowling Alone, New York: Simon and Schuster.

20. Smidt, C. 1999. "Religion and Civic Engagement: A Comparative Analysis". Annals of the American Academy of Political and Social Science, 565: 176-192. Civil Society and Democratization

Review of Social Economy, Vol 68, No. 2 (June 2010): pg. 163-186. DOI. This article is @ Routledge: Taylor \& Francis Group and permission has been granted for this version to appear in e-Publications@Marquette. Routledge: Taylor \& Francis Group does not grant permission for this article to be further copied/distributed or hosted elsewhere without the express permission from Routledge: Taylor \& Francis Group. 
21. Smith, T. W. 1986. "Classifying Protestant Denominations". General Social Survey Methodological Report No. 43, ICPSR, University of Michigan

22. Smith, T. W. 1990. "Classifying Protestant Denominations". Review of Religious Research, 31: 225-245.

23. Tamney, J. B. 1992. The Resilience of Christianity in the Modern World, Albany, NY: SUNY Press.

24. Tomz, M., Wittenberg, J. and King, G. 2001. Clarify: Software for Interpreting and Presenting Statistical Results. Version 2.0 Available at: http://gking.harvard.edu

25. Torgler, B. 2006a. "The Importance of Faith: Tax Morale and Religiosity". Journal of Economic Behavior and Organization, 61: 81-109.

26. Torgler, B. 2006b. "Trust in International Organizations: An Empirical Investigation Focusing on the United Nations". Center for Research in Economics, Management and the Arts, Working Paper No. 2006-20. Available at: http://www.crema-research.ch 27. Welch, M. R., Sikkink, D., Sartain, E. and Bond, C. 2004. "Trust in God and Trust in Man: The Ambivalent Role of Religion in Shaping Dimensions of Social Trust". Journal for the Scientific Study of Religion, 43(3): 317-344.

28. Wuthnow, R. 2002. "Religious Involvement and Status-bridging Social Capital". Journal for the Scientific Study of Religion, 41(4): 669-684. 